\title{
Bacteriocinogenic Lactococcus lactis subsp. lactis DF04Mi isolated from goat milk: Characterization of the bacteriocin
}

\author{
Danielle N. Furtado, Svetoslav D. Todorov, Mariza Landgraf, Maria T. Destro, \\ Bernadette D.G.M. Franco
}

Laboratório de Microbiologia de Alimentos, Departamento de Alimentos e Nutrição Experimental, Faculdade de Ciências Farmacêuticas, Universidade de São Paulo, São Paulo, SP, Brazil.

Submitted: July 12, 2013; Approved: April 17, 2014.

\begin{abstract}
Lactic acid bacteria capable of producing bacteriocins and presenting probiotic potential open innovative technological applications in the dairy industry. In this study, a bacteriocinogenic strain (Lactococcus lactis subsp. lactis DF4Mi) was isolated from goat milk, and studied for its antimicrobial activity. The bacteriocin presented a broad spectrum of activity, was sensitive to proteolytic enzymes, resistant to heat and $\mathrm{pH}$ extremes, and not affected by the presence of SDS, Tween 20, Tween 80, EDTA or NaCl. Bacteriocin production was dependent on the components of the culture media, especially nitrogen source and salts. When tested by PCR, the bacteriocin gene presented $100 \%$ homology to nisin Z gene. These properties indicate that this L. lactis subsp. lactis DF4Mi can be used for enhancement of dairy foods safety and quality.
\end{abstract}

Key words: bacteriocin, probiotic, Lc. lactis subsp. lactis, biopreservation, goat milk.

\section{Introduction}

It is well known that many lactic acid bacteria (LAB) are capable of producing a variety of antimicrobial compounds, which may contribute to their colonization of habitats and their competitive advantage over other bacteria (Garriga et al., 1993; Todorov, 2009). Besides production of lactic acid, which causes a drop in $\mathrm{pH}$ enough to inhibit certain strains, as its non-dissociated form triggers a lowering of the internal $\mathrm{pH}$ in sensitive bacteria that causes a collapse in the electrochemical proton gradient resulting in a bacteriostatic or bactericidal effect (O'Keeffe et al., 1999; Todorov, 2009), LAB can produce other organic acids, diacetyl, hydrogen peroxide, and bacteriocins (Nes and Johnsborg, 2004; Parente and Ricciardi, 1999).

Several bacteriocin-producing LAB strains have been isolated from milk and dairy products (Franco et al., 2011), and particularly from goat milk (Cocolin et al., 2007; Casla et al., 2008; Schirru et al., 2012). However nisin, a lantibiotic produced by Lactococcus lactis subsp. lactis, remains the best studied bacteriocin (Sobrino-Lopez and Martin-Belloso, 2008). Several other bacteriocins produ- ced by Lc. lactis have been described, but are less well known (Piard, 1994; Ko and Ahn, 2000; Ferchichi et al., 2001; Lee and Paik, 2001; Cheigh et al., 2002; Mathara et al., 2004; Todorov and Dicks, 2004; Aslim et al., 2005; Ghrairi et al., 2005; Alomar et al., 2008; Nikolic et al., 2008; Kruger et al., 2013). It is generally accepted that bacteriocins produced by LAB are more active against Gram positive bacteria, however KSA2386, ST34BR and lacticin NK24 are bacteriocins produced by Lc. lactis that present a larger spectrum of activity, being active against Gram-negative bacteria as well (Piard, 1994; Ko and Ahn, 2000; Todorov and Dicks, 2004).

Optimal bacteriocin production for technological applications in dairy products remains a challenge, as production does not always correlate with the increase in cell mass or growth rate of the producer strain. Higher bacteriocin levels are produced in the absence of growth stimulating nutrients, or at temperatures and $\mathrm{pH}$ conditions lower than required for optimal growth (Matsusaki et al., 1996; Kim et al., 1997; Bogovic-Matijasic and Rogelj, 1998; Krier et al., 1998; Aasen et al., 2000; Todorov et al., 2000; Schirru et al., 2012). Optimal bacteriocin production is often recorded 
in media with limiting concentrations of sugars, nitrogen sources, vitamins and potassium phosphate, or when the medium $\mathrm{pH}$ is regulated (Vignolo et al., 1995; Schirru et al., 2012).

Application of bacteriocinogenic strains for dairy product preservation is in agreement with consumers' demands for foods that are naturally preserved. In this study we report results on the isolation of a bacteriocinogenic Lactococcus lactis subsp. lactis strain (Lc. lactis DF04Mi) from raw goat milk and the characterization of the bacteriocin.

\section{Materials and Methods}

\section{Isolation and identification of bacteriocin producing strains}

Screening for bacteriocin-producing isolates from goat milk was carried out according to the triple-agar-layer method used by Todorov et al. (2010). Samples of goat milk obtained from a producer in Ibiúna, SP, Brazil, were submitted to serial decimal dilution with sterile saline $(0.85 \%, w / \mathrm{v} \mathrm{NaCl})$ and plated onto MRS agar (Difco, USA). A second layer of MRS agar (1.7\%, w/v) was applied to the plates to provide anaerobic condition for growth of LAB. The plates were incubated at $30^{\circ} \mathrm{C}$ for $24 \mathrm{~h}$ under anaerobiosis (Anaerocult, Merck, Darmstadt, Germany). Plates containing single colonies were overlaid with a third layer of Brain Heart Infusion (BHI) suplemented by 1\% (w/v) agar (Difco) seeded with Enterococcus faecalis ATCC 19443, Lactobacillus sakei ATCC 15521 or Listeria monocytogenes $711\left(10^{6} \mathrm{cfu} / \mathrm{mL}\right)$, and incubated at $37^{\circ} \mathrm{C}$ for $24 \mathrm{~h}$. Colonies surrounded by a growth inhibition zone of at least $2 \mathrm{~mm}$ in diameter were transferred to MRS broth (Difco) and incubated for $24 \mathrm{~h}$ at $30^{\circ} \mathrm{C}$. Pure cultures, obtained by streaking onto MRS agar (Difco), were submitted to identification by carbohydrate fermentation reactions using API50CHL and API20Strep test strips (Biomérieux, Marcy-I'Etoile, France) and identification confirmed by amplification of genomic DNA with primers F8 and R1512, as described by Felske et al. (1997). The amplified fragments were purified using QIAquick PCR Purification Kit (Qiagen, Valencia, CA, USA), sequenced, and compared to sequences in GenBank using BLAST, Basic Local Alignment Search Tool. Six strains were selected and submitted to bacteriocin bioassay. The strains were inoculated $(2 \%, \mathrm{v} / \mathrm{v})$ into $100 \mathrm{~mL}$ MRS broth and incubated at $30^{\circ} \mathrm{C}$ for $24 \mathrm{~h}$. Cells were harvested $\left(1000 \mathrm{x} \mathrm{g}, 15 \mathrm{~min}, 4{ }^{\circ} \mathrm{C}\right)$, the $\mathrm{pH}$ of the cell-free supernatants adjusted to 6.0 with sterile $1 \mathrm{M} \mathrm{NaOH}$, heated for $10 \mathrm{~min}$ at $80^{\circ} \mathrm{C}$, and then filter-sterilized ( $0.20 \mu \mathrm{m}$, Millipore). Bacteriocin activity was tested against target organisms listed in Table 1, using the agar-spot test method. Target microorganisms included a variety of Gram positive strains isolated from various foods, belonging to the collection of the Food Microbiology Laboratory of University of São Paulo and eight ATCC reference strains. Antimicrobial activity was expressed as arbitrary units (AU)/mL, calculated as follows: $\mathrm{a}^{\mathrm{b}} \mathrm{x} 100$, where "a" represents the dilution factor and " $b$ " the last dilution that produced an inhibition zone of at least $2 \mathrm{~mm}$ in diameter. Strain DF04Mi, identified as Lc. lactis subsp. lactis, presented the largest spectrum of activity, and therefore was selected for further bacteriocin characterization.

\section{Characterization of the bacteriocin DF04Mi}

\section{Sensitivity of bacteriocin to proteolytic enzymes}

One $\mathrm{ml}$ of a cell-free supernatant of strain DF04Mi, prepared as described before, was tested for sensitivity to the following enzymes $(0.1$ and $1.0 \mathrm{mg} / \mathrm{mL})$ : $\alpha$-amylase (Sigma, St. Louis, MO, USA), lipase (Sigma), catalase (Sigma), proteinase K (Roche, Indianapolis, IN, USA), type II bovine $\alpha$-chymotrypsin (Sigma), type XIV protease from Streptomyces griseus (Sigma) and pepsin (Sigma). The mixtures were incubated at $30^{\circ} \mathrm{C}$ for $30 \mathrm{~min}$, heated at 95-97 ${ }^{\circ} \mathrm{C}$ for $5 \mathrm{~min}$, cooled and then tested for activity using E. faecalis ATCC 19443 as sensitive strain.

\section{Effect of $\mathrm{pH}$, temperature and chemicals on stability of bacteriocin DFO4Mi}

The effect of $\mathrm{pH}$ was measured adjusting the $\mathrm{pH}$ of $10 \mathrm{~mL}$ of cell-free supernatant of the culture of Lc. lactis DF04Mi to $2.0,4.0,6.0,8.0$ or 10.0 with $1 \mathrm{M} \mathrm{HCl}$ or $1 \mathrm{M}$ $\mathrm{NaOH}$ and incubating at $30^{\circ} \mathrm{C}$ for $1 \mathrm{~h}$. The effect of temperature on activity was determined incubating supernatants at $30,37,45,60,80$ and $100{ }^{\circ} \mathrm{C}$ for $30 \mathrm{~min}$ and $2 \mathrm{~h}$, and autoclaving at $121{ }^{\circ} \mathrm{C}$ for $20 \mathrm{~min}$. The effect of chemicals was tested adding $10 \mathrm{mg} / \mathrm{mL}$ Tween 20 (Synth, Sao Paulo, Brazil), Tween 80 (Synth), $\mathrm{NaCl}$ (Synth), SDS (Sigma) or EDTA (Sigma) to supernatants and incubating for $30 \mathrm{~min}$ at $30^{\circ} \mathrm{C}$. Before testing for activity, the $\mathrm{pH}$ of all samples was adjusted to 6.0. Activity was tested using E. faecalis ATCC 19443 as sensitive strain.

\section{Effect of $\mathrm{pH}$ and components in MRS broth on bacteriocin production}

Cells of Lc. lactis DF04Mi were washed two times with sterile saline and suspended in sterile saline to the original volume. The resulting cell suspension $(100 \mu \mathrm{L})$ was used to inoculate $10 \mathrm{~mL}$ of MRS broth with $\mathrm{pH}$ adjusted to 4.5, 5.0, 5.5, 6.0 and 6.5, using $1 \mathrm{M} \mathrm{NaOH}$ or $1 \mathrm{M}$ $\mathrm{HCl}$. The cell suspension $(100 \mu \mathrm{L})$ was also used to inoculate $10 \mathrm{~mL}$ of formulated MRS broth (Difco), in which original components were replaced by other chemicals or were added of new ingredients. In the first set of experiments, the concentration of glucose and lactose of formulated MRS broth was adjusted to 5.0, 10.0, 20.0, 30.0 and $50.0 \mathrm{~g} / \mathrm{L}$. In a second set of experiments, glucose of MRS broth was replaced by L-rhamnose, D-manitol, galactose or mannose $(20.0 \mathrm{~g} / \mathrm{L})$. In a third set of experiments, organic nitrogen sources in MRS broth were replaced by $20.0 \mathrm{~g} / \mathrm{L}$ tryptone (Difco) or meat extract (Difco) or yeast extract (Difco), or 
Table 1 - Spectrum of activity of the bacteriocin produced by Lc. lactis subsp. lactis DF04Mi isolated from raw goat milk.

\begin{tabular}{|c|c|c|}
\hline Target microorganism & Medium and growth temperature & Inhibition zone (mm) \\
\hline Listeria monocytogenes ATCC 7644 & $\mathrm{BHI}, 37^{\circ} \mathrm{C}$ & - \\
\hline L. monocytogenes Scott A & $\mathrm{BHI}, 37^{\circ} \mathrm{C}$ & 20 \\
\hline \multicolumn{3}{|l|}{ L. monocytogenes serological group $4 \mathrm{~b}$} \\
\hline Strain 101 & $\mathrm{BHI}, 37^{\circ} \mathrm{C}$ & 15 \\
\hline Strain 211 & $\mathrm{BHI}, 37^{\circ} \mathrm{C}$ & 17 \\
\hline Strain 302 & $\mathrm{BHI}, 37^{\circ} \mathrm{C}$ & 15 \\
\hline Strain 620 & $\mathrm{BHI}, 37^{\circ} \mathrm{C}$ & 14 \\
\hline Strain 703 & $\mathrm{BHI}, 37^{\circ} \mathrm{C}$ & 17 \\
\hline Strain 724 & $\mathrm{BHI}, 37^{\circ} \mathrm{C}$ & 17 \\
\hline \multicolumn{3}{|l|}{ L. monocytogenes serological group $1 / 2 \mathrm{a}$} \\
\hline Strain 103 & $\mathrm{BHI}, 37^{\circ} \mathrm{C}$ & 15 \\
\hline Strain 104 & $\mathrm{BHI}, 37^{\circ} \mathrm{C}$ & 19 \\
\hline Strain 106 & $\mathrm{BHI}, 37^{\circ} \mathrm{C}$ & 15 \\
\hline Strain 409 & $\mathrm{BHI}, 37^{\circ} \mathrm{C}$ & 21 \\
\hline Strain 506 & $\mathrm{BHI}, 37^{\circ} \mathrm{C}$ & 20 \\
\hline Strain 709 & $\mathrm{BHI}, 37^{\circ} \mathrm{C}$ & 15 \\
\hline \multicolumn{3}{|l|}{ L. monocytogenes serological group $1 / 2 \mathrm{~b}$} \\
\hline Strain 426 & $\mathrm{BHI}, 37^{\circ} \mathrm{C}$ & 17 \\
\hline Strain 603 & BHI, $37^{\circ} \mathrm{C}$ & 16 \\
\hline Strain 607 & $\mathrm{BHI}, 37^{\circ} \mathrm{C}$ & 20 \\
\hline \multicolumn{3}{|l|}{ L. monocytogenes serological group $1 / 2 \mathrm{c}$} \\
\hline Strain 408 & $\mathrm{BHI}, 37^{\circ} \mathrm{C}$ & 20 \\
\hline Strain 422 & $\mathrm{BHI}, 37^{\circ} \mathrm{C}$ & 17 \\
\hline Strain 637 & $\mathrm{BHI}, 37^{\circ} \mathrm{C}$ & 15 \\
\hline Strain 711 & $\mathrm{BHI}, 37^{\circ} \mathrm{C}$ & 20 \\
\hline Strain 712 & $\mathrm{BHI}, 37^{\circ} \mathrm{C}$ & 20 \\
\hline Listeria innocua ATCC 33090 & $\mathrm{BHI}, 37^{\circ} \mathrm{C}$ & - \\
\hline Enterococcus faecalis ATCC 19443 & MRS, $30^{\circ} \mathrm{C}$ & 9 \\
\hline E. faecium ST88Ch & MRS, $30^{\circ} \mathrm{C}$ & - \\
\hline E. hirae DF105 & $\mathrm{MRS}, 30^{\circ} \mathrm{C}$ & 15 \\
\hline Lactobacillus acidophilus LA14 & MRS, $30^{\circ} \mathrm{C}$ & - \\
\hline Lb. acidophilus La5 & $\mathrm{MRS}, 30^{\circ} \mathrm{C}$ & - \\
\hline L. acidophilus LAC4 & $\mathrm{MRS}, 30^{\circ} \mathrm{C}$ & - \\
\hline Lactobacillus delbrueckii subsp. bulgaricus B1 & $\mathrm{MRS}, 30^{\circ} \mathrm{C}$ & 10 \\
\hline Lb. delbrueckii subsp. bulgaricus B15 & MRS, $30^{\circ} \mathrm{C}$ & 12 \\
\hline Lb. delbrueckii subsp. bulgaricus B16 & $\mathrm{MRS}, 30^{\circ} \mathrm{C}$ & 14 \\
\hline Lb. delbrueckii subsp. bulgaricus B2 & MRS, $30^{\circ} \mathrm{C}$ & 12 \\
\hline Lb. delbrueckii subsp. bulgaricus B5 & $\mathrm{MRS}, 30^{\circ} \mathrm{C}$ & - \\
\hline Lactobacillus paracasei LBC82 & MRS, $30^{\circ} \mathrm{C}$ & - \\
\hline Lb. paracasei subsp. paracasei DF60Mi & $\mathrm{MRS}, 30^{\circ} \mathrm{C}$ & - \\
\hline Lactobacillus sakei $2 \mathrm{a}$ & MRS, $30^{\circ} \mathrm{C}$ & - \\
\hline Lb. sakei ATCC 15521 & MRS, $30^{\circ} \mathrm{C}$ & 18 \\
\hline Lactococcus lactis subsp. lactis B17 & MRS, $30^{\circ} \mathrm{C}$ & 14 \\
\hline Lc. lactis subsp. lactis DF02Mi & MRS, $30^{\circ} \mathrm{C}$ & 12 \\
\hline Lc. lactis subsp. lactis DF03Mi & $\mathrm{MRS}, 30^{\circ} \mathrm{C}$ & 12 \\
\hline Lc. lactis subsp. lactis MK02R & MRS, $30^{\circ} \mathrm{C}$ & 10 \\
\hline Lc. lactis subsp. lactis R704 & $\mathrm{MRS}, 30^{\circ} \mathrm{C}$ & 15 \\
\hline Lc. lactis subsp. lactis V69 & MRS, $30{ }^{\circ} \mathrm{C}$ & 12 \\
\hline Leuconostoc lactis DF05Mi & MRS, $30^{\circ} \mathrm{C}$ & 12 \\
\hline Staphylococcus aureus ATCC 25923 & $\mathrm{BHI}, 37^{\circ} \mathrm{C}$ & - \\
\hline S. aureus ATCC 29213 & $\mathrm{BHI}, 37^{\circ} \mathrm{C}$ & - \\
\hline S. aureus ATCC 6538 & $\mathrm{BHI}, 37^{\circ} \mathrm{C}$ & - \\
\hline Bacillus cereus ATCC 11778 & $\mathrm{BHI}, 37^{\circ} \mathrm{C}$ & - \\
\hline
\end{tabular}

- = no inhibition observed or inhibition zone $<2 \mathrm{~mm}$ diameter. 
by these protein sources in the following combinations: $12.5 \mathrm{~g} / \mathrm{L}$ tryptone plus $7.5 \mathrm{~g} / \mathrm{L}$ meat extract or $12.5 \mathrm{~g} / \mathrm{L}$ tryptone plus $7.5 \mathrm{~g} / \mathrm{L}$ yeast extract, or $10 \mathrm{~g} / \mathrm{L}$ meat extract plus $10 \mathrm{~g} / \mathrm{L}$ yeast extract, or $10 \mathrm{~g} / \mathrm{L}$ tryptone plus $5.0 \mathrm{~g} / \mathrm{L}$ yeast extract plus $5.0 \mathrm{~g} / \mathrm{L}$ meat extract. In a fourth set of experiments, MRS broth was added of increasing concentrations of glycerol $(0,2.0,5.0,8.0,10.0$ or $20.0 \mathrm{~g} / \mathrm{L})$. In the last set of experiments, formulated MRS was prepared adding $\mathrm{KH}_{2} \mathrm{PO}_{4}$ or $\mathrm{K}_{2} \mathrm{HPO}_{4}$ or tri-ammonium citrate or sodium acetate or Tween 80 (2.0, 5.0, and $10.0 \mathrm{~g} / \mathrm{L})$. All cultures were incubated at $30{ }^{\circ} \mathrm{C}$ for $24 \mathrm{~h}$ and bacteriocin activity was tested against L. monocytogenes 711 .

\section{Adsorption of bacteriocin to the producer cells}

Adsorption of bacteriocin DF04Mi to producer cells was studied according to Yang et al. (1992). The $\mathrm{pH}$ of an $18 \mathrm{~h}$-old culture of Lc. lactis DF04Mi in MRS broth was adjusted to 5.0 and $10.0 \mathrm{~mL}$ were centrifuged at $8000 \mathrm{x} \mathrm{g}$, $15 \mathrm{~min}, 4^{\circ} \mathrm{C}$. The cells were harvested, washed with an equal volume of sterile $0.1 \mathrm{M}$ phosphate buffer $(\mathrm{pH}$ 6.5) and the pellet was re-suspended in $10 \mathrm{~mL} 100 \mathrm{mM} \mathrm{NaCl}$, pre-adjusted to $\mathrm{pH} 2.0$ with $1 \mathrm{M} \mathrm{HCl}$, and stirred for $1 \mathrm{~h}$ at $4{ }^{\circ} \mathrm{C}$. Cells were harvested again $\left(3000 \times \mathrm{g}, 30 \mathrm{~min}, 4^{\circ} \mathrm{C}\right)$ and the cell-free supernatant adjusted to $\mathrm{pH} 7.0$ with sterile $1 \mathrm{M} \mathrm{NaOH}$. Antimicrobial activity in the treated supernatant was tested as previously described.

\section{Effect of bacteriocin on growth of L. monocytogenes 711}

The effect of bacteriocin on growth of L. monocytogenes 711 was measured adding a $20 \mathrm{~mL}$ aliquot of bacteriocin-containing filter-sterilized $(0.22 \mu \mathrm{m}$, Millipore) supernatant ( $\mathrm{pH}$ 6.0) to $100 \mathrm{~mL}$ culture of the pathogen in early exponential and middle exponential phases. The cultures were incubated for $12 \mathrm{~h}$ and optical density readings at $600 \mathrm{~nm}$ were recorded at $1 \mathrm{~h}$ intervals.

The effect of bacteriocin on reduction on the number of viable cells of $L$. monocytogenes 711 was also measured. Early stationary phase (18 h-old) cultures of the pathogen were harvested $\left(5000 \mathrm{x} g, 5 \mathrm{~min}, 4^{\circ} \mathrm{C}\right)$, washed twice with sterile saline and re-suspended in $10 \mathrm{~mL}$ saline. Equal volumes of L. monocytogenes 711 cell suspensions and bacteriocin-containing filter-sterilized supernatant $(\mathrm{pH}$ 6.0) were mixed, and counts of viable $L$. monocytogenes were performed before and after incubation for $1 \mathrm{~h}$ at $37^{\circ} \mathrm{C}$ by plating onto MRS agar and BHI agar. Cell suspensions of L. monocytogenes 711 with no added bacteriocin served as controls.

Adsorption of the bacteriocin to L. monocytogenes 711, E. faecalis ATCC 19433 and Lb. sakei ATCC 15521

Adsorption of bacteriocin DF04Mi to the target pathogens was tested using the method described by Todorov (2008). The strains were grown overnight in BHI broth (L. monocytogenes 711) or MRS (E. faecalis ATCC 19433 and $L$ b. sakei ATCC 15521$)$ at $37^{\circ} \mathrm{C}$ and $30^{\circ} \mathrm{C}$, respectively, and centrifuged ( $\left.8000 \times \mathrm{g}, 15 \mathrm{~min}, 4^{\circ} \mathrm{C}\right)$. Cells were washed twice with sterile $5 \mathrm{mM}$ phosphate buffer $(\mathrm{pH}$ 6.5 ) and re-suspended to the original volume in the same buffer. The $\mathrm{pH}$ was adjusted to 6.5 with sterile $0.1 \mathrm{M}$ $\mathrm{NaOH}$. Each cell suspension was mixed with an equal volume of bacteriocin-containing filter-sterilized supernatant (pH 6.5) and incubated at $37^{\circ} \mathrm{C}$ for $1 \mathrm{~h}$. After removal of the cells $\left(8000 \mathrm{~g}, 15 \mathrm{~min}, 25^{\circ} \mathrm{C}\right)$, the activity of unbound bacteriocin in the supernatant was determined as previously described. All experiments were done in duplicate.

The percentage of bacteriocin adsorption to target cells was calculated according to the following formula:

$\%$ adsorption $=100-\frac{\text { bactericon activity after treatment }}{\text { original bacteriocin activity }}$

The effect of $\mathrm{pH}$ and temperature on the adsorption of bacteriocin to the target cells was tested by adding cell-free supernatant to cell suspensions of L. monocytogenes 711 , E. faecalis ATCC 19433 and Lb. sakei ATCC 15521, as described before, with incubation for $1 \mathrm{~h}$ at $4,25,30$ and $37^{\circ} \mathrm{C}$ at $\mathrm{pH} 6.0$, and at $37^{\circ} \mathrm{C}$ at $\mathrm{pH} 4.0,6.0,8.0$ and 10.0. Cells were harvested $\left(8000 \times \mathrm{g}, 15 \mathrm{~min}, 25^{\circ} \mathrm{C}\right)$, and the $\mathrm{pH}$ of the supernatant was adjusted to 6.0 with sterile $1 \mathrm{M} \mathrm{NaOH}$. Bacteriocin activity was determined as described before. The experiments were done in duplicate.

The effect of inorganic salts and organic compounds on adsorption of bacteriocin to the target cells was also tested. Cell suspensions of L. monocytogenes 711, E. faecalis ATCC 19433 and Lb. sakei ATCC 15521 were prepared as described before and $1 \%(\mathrm{~m} / \mathrm{v}) \mathrm{NaCl}$, Tween 80 , glycerol or SDS was added to the cell suspensions. The $\mathrm{pH}$ of all samples was adjusted to 6.5 with $1 \mathrm{M} \mathrm{NaOH}$ or $1 \mathrm{M} \mathrm{HCl}$. Bacteriocin was added to the treated cells, as described before, and incubated for $1 \mathrm{~h}$ at $37^{\circ} \mathrm{C}$. The cells were harvested $\left(8000 \mathrm{~g}, 15 \mathrm{~min}, 25^{\circ} \mathrm{C}\right)$ and the activity of bacteriocin in the cell-free supernatant determined as previously described. The experiments were done in duplicate.

\section{Search for the nisin gene in Lc. lactis DFO4Mi}

Total DNA of Lc. lactis DF04Mi was extracted using the DNeasy Blood \& Tissue Kit (Qiagen, Valencia, CA, USA), following the manufacturer protocol. Total isolated DNA was amplified with primers NisF, 5-ATG AGT ACA AAA GAT TTC AAC TT-3, and NisR, 5-TTA TTT GCT TAC GTG AAC GC-3, targeting the structural gene of nisin Q as previously reported by de Kruger et al. (2013). The amplification conditions were as follows: $94{ }^{\circ} \mathrm{C}$ for $4 \mathrm{~min}, 35$ cycles of $94{ }^{\circ} \mathrm{C}$ for $45 \mathrm{~s}, 48^{\circ} \mathrm{C}$ for $30 \mathrm{~s}$, and $72{ }^{\circ} \mathrm{C}$ for $45 \mathrm{~s}$, and $72{ }^{\circ} \mathrm{C}$ for $7 \mathrm{~min}$. Generated PCR product were cleaned with QIAquick PCR Purification Kit (Qiagen) and sequenced with an ABI Prism 377 DNA sequencer (PE Biosystems SA). The exact molecular size of mature bacteriocin DF04Mi (without the leader peptide) was determined from the amino acid sequence deduced from the DNA sequence. DNA homology to sequences listed in GenBank was determined using the BLAST program 
(http://blast.ncbi.nlm.nih.gov/blast.cgi). Determination of the temperature responsible for activation/expresion of the nisin operon, including the immunity gene, was done testing growth of Lc. lactis DF04Mi in presence of $1 \%$ solution of nisin (Sigma) at $30{ }^{\circ} \mathrm{C}$ and $37{ }^{\circ} \mathrm{C}$ for $24 \mathrm{~h}$, using the agar-spot test.

\section{Results and Discussion}

The average count of LAB in the raw goat milk samples used as source for isolation of bacteriocinogenic strains was $3.1 \times 10^{4} \mathrm{cfu} / \mathrm{mL}$. Among the LAB screened for antimicrobial activity, six isolates were active against the three indicator strains used in the screening test. One of them, identified as Lactococcus lactis subsp. lactis (Lc. lactis DF04Mi), presented a broad spectrum of activity, and therefore was selected for the characterization of the bacteriocin.

The neutralized cell-free supernatant from 24 h-old cultures of Lc. lactis DF04Mi inhibited the growth of all tested L. monocytogenes strains, except the ATCC 7644 strain (Table 1). Most Lc. lactis, Lb. delbruecki and Leuconostoc spp. strains were inhibited, however all $L$. acidophilus strains were resistant. Staphylococcus aureus and Bacillus cereus strains were not affected by studied bacteriocin. Interestingly, most food isolates were sensitive to the cell-free supernatant of Lc. lactis DF04Mi while almost all ATCC strains were resistant, regardless the species.

The assessment of the inhibitory spectrum is an important characteristic when evaluating possible applications of bacteriocin-producing strains as potential probiotics or starter cultures, as their inhibitory activity plays a relevant role in the competition with other microorganisms in the gastrointestinal tract or food matrix, protecting them from the colonization by foodborne pathogens. The activity of cell-free supernatants of Lc. lactis DF04Mi against most tested L. monocytogenes strains is quite interesting, particularly because $L$. monocytogenes continues to be a relevant pathogen in dairy products, as several recent listeriosis outbreaks were linked to cheeses (Fretz et al., 2010; Koch et al., 2010).

Contrary to what was expected, bacteriocin produced by Lc. lactis DF04Mi did not inhibit the growth of species of bacteria that are known to belong to the same ecological niche, such as Lactobacillus spp. and Enterococcus spp. Similar findings were reported for the bacteriocins produced by other Lc. lactis subsp. lactis isolates from milk products (Nikolic et al., 2008; Kruger et al., 2013).

Treatment of the cell-free supernatant with proteinase $\mathrm{K}$, protease, pepsin or $\alpha$-chymotrypsin resulted in complete inactivation of the antimicrobial activity (Table 2). Treatment with catalase did not affect the activity against the target strains, discarding clearly the involvement of $\mathrm{H}_{2} \mathrm{O}_{2}$ in the antagonism process. Moreover, treatment with $\alpha$-amy- lase and lipase did not affect the antimicrobial activity, suggesting that bacteriocin DF04Mi does not belong to the controversial group IV of the bacteriocins, which contain carbohydrates or lipids in the active molecule. According to De Vuyst \& Vandamme (1994), most bacteriocins are polypeptides but others, like leuconocin S produced by Leuconostoc paramesenteroides (Lewus et al., 1992), carnocin 54 produced by Leuconostoc carnosum (Keppler et al., 1994) and bacteriocin ST63BZ produced by Leuconostoc lactis ST63BZ (Todorov, 2010) are typical examples of amylase-sensitive bacteriocins.

Bacteriocin DF04Mi activity was not affected by SDS, Tween 20, Tween 80, EDTA or $\mathrm{NaCl}$ (Table 2). The sensitivity of bacteriocins to detergents and $\mathrm{NaCl}$ seems to be bacteriocin-dependent and affected by the experimental conditions. Bioactivity of plantaricin C19 was not affected by the presence of SDS or Triton X-100 (Atrih et al., 2001) contrarily to bacteriocins ST311LD (Todorov and Dicks, 2005), plantaricin 423 (Verellen et al., 1998), pediocin PA-1/AcH (Biswas et al., 1991), lactacin B (Barefoot and Klaenhammer, 1984) and lactocin 705 (Vignolo et al., 1995). On the other side, bacteriocin HV219 was sensitive to SDS, Triton X-114 and Triton X-100, but resistant to Tween 20, Tween 80, urea or EDTA (Todorov et al., 2006). Similar results were recorded for bozacin B14 produced by Lc. lactis subsp. lactis B14 (Ivanova et al., 2000), and bacteriocin $\mathrm{J} 46$ produced by Lc. lactis subsp. cremoris (Huot et al., 1996).

As shown in Table 2, bacteriocin DF04Mi is heat resistant $\left(100^{\circ} \mathrm{C}\right.$ for $2 \mathrm{~h}, 121^{\circ} \mathrm{C}$ for $\left.20 \mathrm{~min}\right)$ and remains stable at $\mathrm{pH}$ ranging from 2.0 to 10.0 for $2 \mathrm{~h}$. A number of studies have shown that heat and $\mathrm{pH}$ resistance of bacteriocins are also bacteriocin-dependent. Bacteriocins produced by other Lactobacillus and Lactococcus strains presented results similar to bacteriocin DF04Mi (Klaenhammer, 1988; Verellen et al., 1998; Todorov et al., 1999; Todorov and Dicks, 2004; Kruger et al., 2013). However, lactocin NK24, produced by Lc. lactis, lost $87.5 \%$ of its activity after $30 \mathrm{~min}$ at $100^{\circ} \mathrm{C}$ and was completely inactivated after $15 \mathrm{~min}$ at $121{ }^{\circ} \mathrm{C}$ (Lee and Paik, 2001). In the case of lactocin MMFII produced by Lc. lactis, only $8.3 \%$ of activity was recorded after $30 \mathrm{~min}$ at $110^{\circ} \mathrm{C}$ or $25 \%$ after $30 \mathrm{~min}$ at $80{ }^{\circ} \mathrm{C}$ and $100{ }^{\circ} \mathrm{C}$ (Ferchichi et al., 2001). Nisin, produced by Lc. lactis WNC20, was inactivated after 15 min at $121{ }^{\circ} \mathrm{C}$ when incubated at $\mathrm{pH} 7.0$, but not when incubated at $\mathrm{pH} 3.0$ at this temperature (Noonpakdee et al., 2003). Bozacin B14, produced by Lc. lactis, was inactivated after $10 \mathrm{~min}$ at $90{ }^{\circ} \mathrm{C}$ (Ivanova et al., 2000).

Low levels of activity (200 AU/mL) for bacteriocin DF04Mi was recorded after treatment of the producer cells with $100 \mathrm{mM} \mathrm{NaCl}$ at $\mathrm{pH} 2.0$ suggesting adhesion of the bacteriocin to the surface of the producer cells. Similar result was reported for bacteriocin HV219 (Todorov et al., 2006), while the opposite was reported for plantaricin ST31 (Todorov et al., 2000) and bozacin B14 (Ivanova et al., 
Table 2 - Activity of bacteriocin produced by Lactococcus lactis subsp lactis DF04Mi after treatment with enzymes, pH, heat and detergents.

\begin{tabular}{lcc}
\hline & Concentration & Activity of bacteriocin DF04Mi* \\
\hline Enzymes & 0.1 and $1.0 \mathrm{~g} / \mathrm{L}$ & + \\
$\quad \alpha$-amylase, lipase, catalase & & + \\
Proteinase $\mathrm{K}, \alpha$-chymotrypsin, protease, pepsin & & + \\
$\mathrm{pH}$ & & + \\
$2-6$ & & + \\
$8-10$ & & + \\
Temperature & & + \\
$100,80,60,45,37,30,20,4^{\circ} \mathrm{C}$ for $1 \mathrm{~h}$ & & + \\
$100,80,60,45,37,30,20,4^{\circ} \mathrm{C}$ for $2 \mathrm{~h}$ & & + \\
$121{ }^{\circ} \mathrm{C}$ for 20 min & & \\
\hline
\end{tabular}

$*+=$ presence of inhibition zone $(>2 \mathrm{~mm})$.

- = no inhibition.

2000). In the case of plantaricin $\mathrm{C} 19$, maximal adsorption to the producer cells was recorded between $\mathrm{pH} 5.0$ and 7.0, with a complete loss of adsorption at $\mathrm{pH} 1.5$ and 2.0 (Atrih et al., 2001).

L. lactis DF04Mi grew well both at $30^{\circ} \mathrm{C}$ and $37^{\circ} \mathrm{C}$, but bacteriocin production occurred only at $30{ }^{\circ} \mathrm{C}$. The maximum bacteriocin production at this temperature was $3200 \mathrm{AU} / \mathrm{mL}$ (Table 3). Lc. lactis DF04Mi did not grow in MRS with an initial $\mathrm{pH}$ of 4.5 , and consequently, no bacteriocin could be detected. Low levels of bacteriocin DF04Mi (400 AU/mL) were recorded in MRS broth adjusted to $\mathrm{pH}$ 5.0. In the same medium adjusted to $\mathrm{pH} 5.5$, only $800 \mathrm{AU} / \mathrm{mL}$ of bacteriocin was recorded. The highest level (3200 AU/mL) was recorded after $18 \mathrm{~h}$ in MRS adjusted to an initial $\mathrm{pH}$ of 6.0 or 6.5 . The final $\mathrm{pH}$ values of the cultures were approximately the same $(\mathrm{pH} 4.3)$, irrespective of the initial $\mathrm{pH}$.

Growth of Lc. lactis DF04Mi in MRS containing rhamnose, manitol, mannose or galactose instead of glucose yielded reduced or absence of bacteriocin production (Table 3). When the concentration of glucose was increased from $5.0 \mathrm{~g} / \mathrm{L}$ to $20.0 \mathrm{~g} / \mathrm{L}$, the production of bacteriocin increased from $400 \mathrm{AU} / \mathrm{mL}$ to $3200 \mathrm{AU} / \mathrm{mL}$, but higher concentrations reduced the amount of bacteriocin in the medium. Similar results were reported for bacteriocin HV219 (Todorov et al., 2006). When glucose was replaced by lactose (at concentrations from 0.5 to $50.0 \mathrm{~g} / \mathrm{L}$ ) production of bacteriocin increased from $800 \mathrm{AU} / \mathrm{mL}$ to $1600 \mathrm{AU} / \mathrm{mL}$. Similar results were recorded for sakacin $\mathrm{P}$ (Aasen et al., 2000) and nisin (De Vuyst and Vandamme, 1994).

As shown in Table 3, the maximum production of bacteriocin DF04Mi in MRS broth supplemented with tryptone, meat extract or yeast extract, or combinations of two of these ingredients, was $800 \mathrm{AU} / \mathrm{mL}$. However, when the three organic nitrogen sources were present simultaneo- usly, the amount of bacteriocin increased four-fold (3200 AU/mL). The influence of the nitrogen source in the culture medium on the production of bacteriocins was also observed in other studies. For bacteriocin HV219, yeast extract was the best nitrogen compound (Todorov et al., 2006), while for plantaricin 423, highest production was obtained in MRS broth supplemented with bacteriological peptone, followed by casamino acids, tryptone and meat extract (Verellen et al., 1998).

Glycerol in MRS medium presented a marked influence in bacteriocin production. The highest production (3200 AU/mL) was obtained when glycerol was absent or when the concentration was below $5.0 \mathrm{~g} / \mathrm{L}$ (Table 3). Glycerol above $5.0 \mathrm{~g} / \mathrm{L}$ resulted in reduced bacteriocin production.

Presence of $\mathrm{MgSO}_{4}$ and $\mathrm{MnSO}_{4}$ and appropriate amounts of tri-ammonium citrate or sodium acetate were essential for production of bacteriocin DF04Mi. $\mathrm{K}_{2} \mathrm{HPO}_{4}$ is also an important ingredient for bacteriocin production in MRS. Lower levels of bacteriocin DF04Mi were recorded when $\mathrm{KH}_{2} \mathrm{PO}_{4}$ was used as replacement for $\mathrm{K}_{2} \mathrm{HPO}_{4}$ (Table 3). However, 5.0 and $10.0 \mathrm{~g} / \mathrm{L} \mathrm{K}_{2} \mathrm{HPO}_{4}$ yielded reduced levels of bacteriocin compared with $2.0 \mathrm{~g} / \mathrm{L} \mathrm{K}_{2} \mathrm{HPO}_{4}$, which corresponds to the concentration of $\mathrm{K}_{2} \mathrm{HPO}_{4}$ in commercial MRS medium. Previous studies conducted with bacteriocin HV219 have shown that increasing the concentration of $\mathrm{K}_{2} \mathrm{HPO}_{4}$ from $2.0 \mathrm{~g} / \mathrm{L}$ to $10.0 \mathrm{~g} / \mathrm{L}$ an increase of $400 \%$ in bacteriocin activity was achieved (Todorov et al., 2006). In the case of the bacteriocin produced by Lb. plantarum UG1, a minimal level of $7.0 \mathrm{~g} / \mathrm{L} \mathrm{K}_{2} \mathrm{HPO}_{4}$ was required for bacteriocin production (Enan et al., 1996). Similar results were reported for plantaricin ST31 (Todorov et al., 2000).

Addition of $3200 \mathrm{AU} / \mathrm{mL}$ bacteriocin DF04Mi to a 3 h-old culture of L. monocytogenes 711 resulted in growth 
Table 3 - Effect of $\mathrm{pH}$ and components added to formulated MRS broth on the production of bacteriocin DF04Mi at $30{ }^{\circ} \mathrm{C}$ for $24 \mathrm{~h}$.

\begin{tabular}{|c|c|c|}
\hline $\mathrm{pH}$ or medium component & $\begin{array}{l}\text { Concentration } \\
(\mathrm{g} / \mathrm{L})\end{array}$ & $\begin{array}{c}\text { bacteriocin } \\
\text { activity* } \\
(\mathrm{AU} / \mathrm{mL})\end{array}$ \\
\hline $\mathrm{pH} 4.5$ & & 0 \\
\hline pH 5.0 & & 400 \\
\hline pH 5.5 & & 800 \\
\hline pH 6.0 & & 3200 \\
\hline pH 6.5 & & 3200 \\
\hline Glucose & 50.0 & 200 \\
\hline Lactose & 5.0 & 800 \\
\hline Lactose & 10.0 & 800 \\
\hline Lactose & 20.0 & 1600 \\
\hline Lactose & 30.0 & 1600 \\
\hline Lactose & 50.0 & 800 \\
\hline L-Rhamnose & 20 & 0 \\
\hline D-Manitol & 20 & 400 \\
\hline Galactose & 20 & 0 \\
\hline Mannose & 20 & 400 \\
\hline Tryptone & 20 & 800 \\
\hline Meat extract & 20 & 400 \\
\hline Yeast extract & 20 & 800 \\
\hline Tryptone and meat extract & $12.5+7.5$ & 400 \\
\hline Tryptone + yeast extract & $12.5+7.5$ & 800 \\
\hline Meat extract + yeast extract & $10.0+10.0$ & 800 \\
\hline Tryptone + yeast extract + meat extract & $10.0+5.0+5.0$ & 3200 \\
\hline Glycerol & 0 & 3200 \\
\hline Glycerol & 2.0 & 3200 \\
\hline Glycerol & 5.0 & 3200 \\
\hline
\end{tabular}

\begin{tabular}{|c|c|c|}
\hline $\mathrm{pH}$ or medium component & $\begin{array}{c}\text { Concentration } \\
(\mathrm{g} / \mathrm{L})\end{array}$ & $\begin{array}{c}\text { bacteriocin } \\
\text { activity* } \\
(\mathrm{AU} / \mathrm{mL})\end{array}$ \\
\hline Glycerol & 8.0 & 1600 \\
\hline Glycerol & 10.0 & 1600 \\
\hline Glycerol & 20.0 & 800 \\
\hline $\mathrm{KH}_{2} \mathrm{PO}_{4}$ & 2.0 & 400 \\
\hline $\mathrm{KH}_{2} \mathrm{PO}_{4}$ & 5.0 & 400 \\
\hline $\mathrm{KH}_{2} \mathrm{PO}_{4}$ & 10.0 & 400 \\
\hline $\mathrm{K}_{2} \mathrm{HPO}_{4}$ & 0 & 0 \\
\hline $\mathrm{K}_{2} \mathrm{HPO}_{4}$ & 2.0 & 3200 \\
\hline $\mathrm{K}_{2} \mathrm{HPO}_{4}$ & 5.0 & 800 \\
\hline $\mathrm{K}_{2} \mathrm{HPO}_{4}$ & 10.0 & 800 \\
\hline $\mathrm{MgSO}_{4}$ & 0 & 400 \\
\hline $\mathrm{MgSO}_{4}$ & 0.1 & 3200 \\
\hline $\mathrm{MnSO}_{4}$ & 0 & 800 \\
\hline $\mathrm{MnSO}_{4}$ & 0.05 & 3200 \\
\hline Tri-ammonium citrate & 0 & 0 \\
\hline Tri-ammonium citrate & 2.0 & 3200 \\
\hline Tri-ammonium citrate & 5.0 & 800 \\
\hline Sodium acetate & 0 & 800 \\
\hline Sodium acetate & 2.0 & 400 \\
\hline Sodium acetate & 5.0 & 3200 \\
\hline Tween 80 & 0 & 3200 \\
\hline Tween 80 & 2.0 & 3200 \\
\hline Tween 80 & 5.0 & 3200 \\
\hline Tween 80 & 10.0 & 3200 \\
\hline
\end{tabular}

*test microorganism Listeria monocytogenes 711.

inhibition for at least $12 \mathrm{~h}$ (data not shown). When cells at stationary phase were treated with bacteriocin DF04Mi, no viable cells of $L$. monocytogenes 711 were detected after $1 \mathrm{~h}$ contact time, regardless the amount of cells submitted to treatment (data not shown). Other bacteriocins, such as those produced by Pediococcus acidilactici HA-6111-2 and E. faecium ST5Ha, presented a similar behaviour (Albano et al., 2007; Todorov et al., 2010).

Adsorption of bacteriocin DF04Mi to L. monocytogenes 711, Lb. sakei ATCC 15521 and E. faecalis ATCC 19433 varied according to the $\mathrm{pH}$, temperature and chemicals in the culture medium (Table 4). Optimal adsorption to L. monocytogenes 711 and Lb. sakei ATCC 15521 was recorded at $\mathrm{pH} 4.0$ and 6.0. Adsorption to E. faecalis ATCC 19443 was lower when compared to the two other microorganisms, regardless the $\mathrm{pH}$. Various studies, conducted with other bacteriocins, have reported different levels of adsorption to different target cells. In the case of buchnericin LB, optimal adsorption to Lb. plantarum was recorded at $\mathrm{pH} 5.0$ - 8.0 (Yildirim et al.,
2002). Optimal adsorption of plantaricin 423 to E. faecium HKLHS was recorded between $\mathrm{pH} 8.0$ and 10.0, and to $L b$. sakei DSM 20017 between pH 2.0 and 6.0 (Todorov and Dicks, 2006). These results suggest that application of bacteriocin DF04Mi at neutral or moderately acid $\mathrm{pH}$ is more effective than at other $\mathrm{pH}$. Differences in adsorption affected by $\mathrm{pH}$ rates may be due to specific interaction between bacteriocin DF04Mi and the target strain or structural pH-dependent modification of the bacteriocin receptors on the target cell surface.

As observed for bacteriocin DF04Mi, bacteriocin HV219, produced by Lc. lactis subsp. lactis HV219, presented the highest levels of adsorption to sensitive strains compared to strains resistant to bacteriocin (Todorov et al., 2007). In the case of plantaricin 423, adsorption ranged from 17\% for Streptococcus caprinus ATCC 700066 to 67\% for Lb. plantarum LMG 13556, Lb. curvatus DF38, L. innocua LMG 13568 and Lb. sakei DSM 20017. Strains sensitive to plantaricin 423 presented a stronger adsorption, 
Table 4 - Effect of $\mathrm{pH}$, temperature, and chemicals on adsorption of bacteriocin DF04Mi to Listeria monocytogenes 711, Lactobacillus sakei ATCC 15521 and Enterococcus faecalis ATCC 19433.

\begin{tabular}{|c|c|c|c|}
\hline & $\begin{array}{c}\text { L. monocytogenes } \\
711\end{array}$ & $\begin{array}{c}\text { L. sakei ATCC } \\
15521\end{array}$ & $\begin{array}{c}\text { E. faecalis } \\
\text { ATCC } 19433\end{array}$ \\
\hline Control & $50 *$ & 50 & 25 \\
\hline \multicolumn{4}{|l|}{$\mathrm{pH}$} \\
\hline 4.0 & 50 & 75 & 50 \\
\hline 6.0 & 50 & 50 & 25 \\
\hline 8.0 & 25 & 25 & 25 \\
\hline 10.0 & 0 & 25 & 0 \\
\hline \multicolumn{4}{|c|}{$\begin{array}{l}\text { Temperature } \\
\left({ }^{\circ} \mathrm{C}\right) \text { : }\end{array}$} \\
\hline 4 & 75 & 75 & 50 \\
\hline 25 & 75 & 75 & 50 \\
\hline 30 & 50 & 50 & 25 \\
\hline 37 & 50 & 50 & 25 \\
\hline \multicolumn{4}{|c|}{ Chemicals (1\%) } \\
\hline glycerol & 25 & 50 & 25 \\
\hline $\mathrm{NaCl}$ & 75 & 75 & 50 \\
\hline SDS & 50 & 50 & 25 \\
\hline Tween 20 & 25 & 25 & 25 \\
\hline Tween 80 & 25 & 25 & 25 \\
\hline
\end{tabular}

* results presenting the \% of adsorption of bacteriocin produced by $L$. lactis DF04Mi to Listeria monocytogenes 711, Lactobacillus sakei ATCC 15521 and Enterococcus faecalis ATCC 19433, respectively.

probably due to the presence of the recognition site on the cell surface on sensitive strains (Todorov and Dicks, 2006).

Highest absorption of bacteriocin DF04Mi to target cells was observed at $4{ }^{\circ} \mathrm{C}$ or $25^{\circ} \mathrm{C}$ than at $30{ }^{\circ} \mathrm{C}$ or $37^{\circ} \mathrm{C}$ (Table 4). Previous studies have also detected the influence of temperature on adsorption of bacteriocins to the surface of bacteria, in a bacteriocin dependent manner. Higher adsorption to E. faecium HKLHS at lower temperatures was also observed for bacteriocin HV219 but not for plantaricin 423 (Todorov and Dicks, 2006), but adsorption of bacteriocin AMA-K to L. innocua LMG 13568, L. monocytogenes Scott A and L. ivanovii subsp. ivanovii ATCC 19119 was higher at $45^{\circ} \mathrm{C}$ than at $30^{\circ} \mathrm{C}$ and $37^{\circ} \mathrm{C}$, while low tempera- tures $\left(4^{\circ} \mathrm{C}\right.$ and $\left.15^{\circ} \mathrm{C}\right)$ resulted in reduction of adsorption (Todorov, 2008).

Tween 20 and Tween 80 caused a decrease in adsorption of bacteriocin DF04Mi to L. monocytogenes 711 and Lb. sakei ATCC 15521, but not to E. faecium ATCC 19433 (Table 4). SDS did not affect the adsorption to any of the tested organisms, while glycerol caused a reduced adsorption to L. monocytogenes 711 but not to the other strains. $\mathrm{NaCl}$ caused an increase in the absorption of bacteriocin DF04Mi to all tested strains. This may have a positive effect if the bacteriocin will be applied in cheese production, because of the presence of $\mathrm{NaCl}$ in the food matrix. Other studies with bacteriocins AMA-K and HV219 indicated that surfactants and solvents such as Tween 20, Tween 80 , Triton X-100, $\beta$-mercapto-ethanol, ethanol, methanol, and chloroform, and salts such as $\mathrm{NaCl}$, sodium nitrate, $\mathrm{KH}_{2} \mathrm{PO}_{4}, \mathrm{MgCl}_{2}$, sodium acetate, $\mathrm{Na}_{2} \mathrm{CO}_{3}, \mathrm{~K}_{2} \mathrm{HPO}_{4}$, $\mathrm{KH}_{2} \mathrm{PO}_{4}, \mathrm{MgCl}_{2}, \mathrm{KCl}$ and others affect the adsorption in different ways, depending on the bacteriocin and the target bacteria (Todorov et al., 2007; Todorov, 2009).

In the search for the nisin gene in Lc. lactis DF04Mi, the sequenced PCR product presented $100 \%$ homology to nisin Z (Figure 1). Variants of nisin producing Lc. lactis have been previously reported (Aso et al., 2008). However, when we tested the effect of $1 \%$ commercial nisin on growth of Lc. lactis DF04Mi (by spot-on-lawn method) at $30^{\circ} \mathrm{C}$ and $37^{\circ} \mathrm{C}$ we have observed that strain DF04Mi was sensitive only if the test was performed at $37^{\circ} \mathrm{C}$. As been previously pointed in this study, Lc. lactis DF04Mi produces bacteriocin only if it was cultivated at $30^{\circ} \mathrm{C}$. Taking in consideration that bacteriocin structural gene and the immunity gene are belong to the same operon, we can conclude that most probably bacteriocin immunity gene is not expressed neither at $37^{\circ} \mathrm{C}$. This observation, combined with the results for the effect of commercial nisin on $L c$. lactis DF04Mi at $30^{\circ} \mathrm{C}$ and $37^{\circ} \mathrm{C}$ pointing that most probably Lc. lactis DF04Mi expressing a nisin. Future studies on purification of the bacteriocin produced under different growth conditions, followed by identification by mass spectrometry and partial or complete amino acid sequencing, are necessary to provide evidence that the gene responsible for synthesis of the bacteriocin produced by Lc. lactis DF04Mi is expressed. Several studies have shown that ex-

\begin{tabular}{|c|c|c|c|c|c|c|}
\hline & -20 & -10 & 1 & 10 & 20 & 30 \\
\hline DF04Mi: & MSTKDFNLDLV & SVSKKDS & GASPRITSIS & LCTPGCKTGA & LMGCNMKTAT & CNCS_HVSK \\
\hline Nisin Z: & MSTKDFNLDLV & SVSKKDS & GASPRITSIS & LCTPGCKTG $\underline{A}$ & LMGCNMKKTAT & CNCS_HVSK \\
\hline Nisin F: & MSTKDFNLDLV & SVS $\underline{\text { KKDS }}$ & GASPRITSIS & LCTPGCKTGA & LMGCNMKTAT & CNCSE $\underline{H V S K}$ \\
\hline Nisin A: & MSTKDFNLDLV & 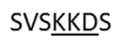 & GASPRITSIS & LCTPGCKTGA & 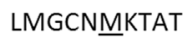 & CHCS_HVVSK \\
\hline Nisin Q: & MSTKDFNLDLV & SVSKKTOS & GASPRITSIS & LCTPGCKTG $\underline{V}$ & LMGCN_LKTAT & CNCSEVHVSK \\
\hline
\end{tabular}

Figure 1 - Amino acid sequence of the bacteriocin produced by Lactococcus lactis subsp lactis DF04Mi, compared to nisin Z, nisin F, nisin A and nisin Q. The leader peptide of each nisin variant consists of 13 amino acids (from position -13 to -1), followed by amino acids encoding the mature protein (amino acid positions 1 to 34) Differences in amino acids are indicated in bold. 
pression of structural bacteriocin genes is affected by the conditions in which the bacteriocin producing strain is cultivated (Vignolo et al., 1995; Matsusaki et al., 1996; Krier et al., 1998; Aasen et al., 2000; Poeta et al., 2007).

\section{Acknowledgments}

This research was supported by grants from FAPESP (Sao Paulo, SP), CAPES (Brasilia, DF) and CNPq (Brasilia, DF), Brazil.

\section{References}

Aasen IM, Moreto T, Katla T, Axelsson L, Storro I (2000) Influence of complex nutrients, temperature and $\mathrm{pH}$ on bacteriocin production by Lactobacillus sakei CCUG 42687. Appl Microbiol Biotechnol 53:159-166.

Albano H, Todorov SD, van Reenen CA, Hogg T, Dicks LMT, Teixeira P (2007) Characterization of a bacteriocin produced by Pediococcus acidilactici isolated from "Alheira", a fermented sausage traditionally produced in Portugal. Int J Food Microbiol 116:239-247.

Alomar J, Loubiere P, Delbes C, Nouaille S, Montel MC (2008) Effect of Lactococcus garvieae, Lactococcus lactis and Enterococcus faecalis on the behaviour of Staphylococcus aureus in microfiltered milk. Food Microbiol 25:502-508.

Aslim B, Yuksekdag ZN, Sarikaya E, Beyatli Y (2005) Determination of the bacteriocin-like substances produced by some lactic acid bacteria isolated from Turkish dairy products. LWT Food Sci Technol 38:691-694.

Aso Y, Takeda A, Sato M, Takahashi T, Yamamoto T, Yoshikiyo K (2008) Characterization of lactic acid bacteria coexisting with a nisin $\mathrm{Z}$ producer in Tsuda-turnip pickles. Curr Microbiol 57:89-94.

Atrih A, Rekhif N, Moir AJG, Lebrihi A, Lefebvre G (2001) Mode of action, purification and amino acid sequence of plantaricin $\mathrm{C} 19$, an anti-Listeria bacteriocin produced by Lactobacillus plantarum C19. Int J Food Microbiol 68:93109.

Barefoot SF, Klaenhammer TR (1984) Purification and characterization of the Lactobacillus acidophilus bacteriocin lactacin B. Antimicr Agents Chemother 26:328-334.

Biswas SR, Ray P, Johnson MC, Ray B (1991) Influence of growth conditions on the production of a bacteriocin, pediocin AcH, by Pediococcus acidilactici $\mathrm{H}$. Appl Environ Microbiol 57:1265-1267.

Bogovic-Matijasic B, Rogelj I (1998) Bacteriocin complex of Lactobacillus acidophilus LF221 - production studies in MRS-media at different $\mathrm{pH}$ values and effect against Lactobacillus helveticus ATCC 15009. Process Biochem 33:345-352.

Casla D, Requena T, Gómez R (2008) Antimicrobial activity of lactic acid bacteria isolated from goats milk and artisanal cheeses: characteristics of a bacteriocin produced by Lactobacillus curvatus IFPL105. J Appl Microbiol 81:3541.

Cheigh C-I, Choi H-J, Park H, Kim S-B, Kook M-C, Kim T-S, Hwang J-K, Pyun Y-R (2002) Influence of growth conditions on the production of a nisin-like bacteriocin by Lactococcus lactis subsp. lactis A164 isolated from kimchi. J Biotechnol 95:225-235.
Cocolin L, Foschino R, Comi G, Fortina MG (2007) Description of the bacteriocins produced by two strains of Enterococcus faecium isolated from Italian goat milk. Food Microbiol 24:752-758.

De Vuyst L, Vandamme E (1994) Bacteriocins of lactic acid bacteria, Blackie London, United Kingdom pp. 539.

Enan G, Essawy AA, Uyttendaele M, Debevere J (1996) Antibacterial activity of Lactobacillus plantarum $\mathrm{UG} 1$ isolated from dry sausage: Characterization, production and bactericidal action of plantaricin UG1. Int J Food Microbiol 30:189-215.

Felske A, Rheims H, Wolterink A, Stackebrandt E, Akkermans ADL (1997) Ribosome analysis reveals prominent activity of an uncultured member of the class Acinetobacteria in grassland soils. Microbiol 143:2983-2989.

Ferchichi M, Frere J, Mabrouk K, Manai M (2001) Lactocin MMFII, a novel class IIa bacteriocin produced by Lactococcus lactis MMFII, isolated from Tunisian dairy product. FEMS Microbiol Lett 205:49-55.

Franco BDGM, De Martinis ECP, Todorov SD (2011) Bioconservação de produtos lácteos probióticos e não probióticos empregando bacteriocinas de bactérias láticas. In: Probióticos e Prebióticos em Alimentos. Fundamentos e Aplicações Tecnológicas. Saad SMI, da Cruz AG, Faria JAF (eds) Varela Publisher, São Paulo, pp. 121-140,.

Fretz R, Pichler J, Sagel U, Much P, Ruppitsch W, Pietzka AT, Stoger A, Huhulescu S, Heuberger S, Appl G, Werber D, Stark K, Prager R, Flieger A, Karpiskova R, Pfaff G, Allerberger F (2010) Multinational listeriosis outbreak due to quargel, a sour milk curd cheese, caused by two different $L$. monocytogenes serotype 1/2a strains, 2009-2010. Eurosurveillance 15:2-3.

Garriga M, Hugas M, Aymerich T, Monfort JM (1993) Bacteriocinogenic activity of Lactobacillli from fermented susages. J Appl Bacteriol 75:142-148.

Ghrairi T, Frere J, Berjaud JM, Manai M (2005) Lactococcin MMT24, a novel two-peptide bacteriocin produced by Lactococcus lactis isolated from rigouta cheese. Int J Food Microbiol 105:389-398.

Huot E, Maghrous J, Barena-Gonzalez C (1996) Bacteriocin J46, a new bacteriocin produced by Lactococcus lactis subsp. cremoris J46: isolation and characterization of the protein and its gene. Anaerobe 2:137-145.

Ivanova I, Kabadjova P, Pantev A, Danova S, Dousset X (2000) Detection, purification and partial characterization of a novel bacteriocin substance produced by Lactococcus lactis subsp. lactis B14 isolated from boza-Bulgarian traditional cereal beverage. Biocatalysis 41:47-53.

Keppler K, Geisen R, Holzapfel WH (1994) An $\alpha$-amylase sensitive bacteriocin of Leuconostoc carnosum. Food Microbiol 11:39-45.

Kim WS, Hall RJ, Bunn NW (1997) The effect of nisin concentration and nutritient depletion on nisin production of Lactococcus lactis. Appl Microbiol Biotechnol 48:449-453.

Klaenhammer TR (1988) Bacteriocins of lactic acid bacteria. Biochimie 70:337-349.

Ko S-H, Ahn C (2000) Bacteriocin production by Lactococcus lactis KCA2386 isolated from white kimachi. Food Sci Biotechnol 9:263-269.

Koch J, Dworak R, Prager R, Becker B, Brockmann S, Wicke A, Wichmann-Schauer H, Hof H, Werber D, Stark K (2010) Large listeriosis outbreak linked to cheese made from pas- 
teurized milk, Germany, 2006-2007. Foodborne Path Dis 7:1581-1584.

Krier F, Revol-Junelles AM, Germain P (1998) Influence of temperature and $\mathrm{pH}$ on production of two bacteriocins by Leuconostoc mesenteroides subsp. mesenteroides FR52 during batch fermentation. Appl Microbiol Biotechnol 50:359-363.

Kruger MF, Barbosa MS, Miranda A, Landgraf M, Destro MT, Todorov SD, Franco BDGM (2013) Isolation of bacteriocinogenic strain of Lactococcus lactis subsp. lactis from Rocket salad (Eruca sativa Mill.) and evidences of production of a variant of nisin with modification in the leader -peptide. Food Control 33:467-476.

Lee N-K, Paik H-D (2001) Partial characterization of lacticin NK24, a nowly identified bacteriocin of Lactococcus lactis NK24 isolated from Jeot-gal. Food Microbiol 18:17-24.

Lewus CB, Sun S, Montville JT (1992) Production of an $\alpha$-amylase sensitive bacteriocin by an atypical Leuconostoc paramesenteroides strain. Appl Environ Microbiol 58:143149.

Mathara JM, Schillinger U, Kutima PM, Mbugua SK, Holzapfel WH (2004) Isolation, identification and characterization of the dominant microorganisms of kule naoto, the Maasai traditional fermented milk in Kenya. Int J Food Microbiol 9:269-278.

Matsusaki H, Endo N, Sonomoto K, Ishizaki A (1996) Lantibiotic nisin $\mathrm{Z}$ fermentative production by Lactococcus lactis IO-1: Relationship between production of the lantibiotic and lactate and cell growth. Appl Microbiol Biotechnol 45:36-40.

Nes I, Johnsborg O (2004) Exploration of antimicrobial potential of LAB by genomics. Curr Opin Biotechnol 15:1-5.

Nikolic M, Terzic-Vidojevic A, Jovcic B, Begovic J, Golic N, Topisirovic L (2008) Characterization of lactic acid bacteria isolated from Bukuljac, a homemade goat's milk cheese. Int J Food Microbiol 122:162-170.

Noonpakdee W, Santivarangkna C, Jumriangrit P, Sonomoto K, Panyim S (2003) Isolation of nisin-producing Lactococcus lactis WNC20 strain from nham, a traditional Thai fermented sausage. Int J Food Microbiol 81:137-145.

O'Keeffe T, Hill C, Ross RP (1999) Characterization and heterologous expression of the genes encoding enterocin A production, immunity, and regulation in Enterococcus faecium DPC1146. Appl Environ Microbiol 65:1506-1515.

Parente E, Ricciardi A (1999) Production, recovery and purification of bacteriocins from lactic acid bacteria. Appl Microbiol Biotechnol 52:628-638.

Piard JC (1994) Bacteriocins of lactic acid bacteria: Microbiology, genetics and applications. London: Blackie Academic and Professional.

Poeta P, Costa D, Rojo-Bezares B, Zarazaga M, Klibi N, Rodrigues J, Torres C (2007) Detection of antimicrobial activities and bacteriocin structural genes in faecal enterococci of wild animals. Microbiol Res 162:257-263.

Schirru S, Todorov SD, Favaro L, Mangia NP, Basaglia M, Casella S, Comunian R, Franco BDGM, Deiana P (2012) Sardinian goat's milk as source of bacteriocinogenic potential protective cultures. Food Control 25:309-320.

Sobrino-López A, Martín-Belloso O (2008) Use of nisin and other bacteriocins for preservation of dairy products. Int Dairy $\mathrm{J}$ 18:329-343.
Todorov S, Gotcheva B, Dousset X, Onno B, Ivanova I (2000) Influence of growth medium on bacteriocin production in Lactobacillus plantarum ST31. Biotechnol Biotechnol Eq 14:50-55.

Todorov S, Onno B, Sorokine O, Chobert JM, Ivanova I, Dousset X (1999) Detection and characterization of a novel antibacterial substance produced by Lactobacillus plantarum ST31 isolated from sourdough. Int J Food Microbiol 48:167-177.

Todorov SD, Dicks LMT (2004) Influence of growth conditions on the production of a bacteriocin by Lactococcus lactis subsp. lactis ST34BR, a strain isolated from barley beer. J Basic Microbiol 44:305-316.

Todorov SD, Dicks LMT (2005) Optimization of bacteriocin ST311LD production by Enterococcus faecium ST311LD, isolated from spoiled black olives. J Microbiol 43:370-374.

Todorov SD, Dicks LMT (2006) Parameters affecting the adsorption of plantaricin 423, a bacteriocin produced by Lactobacillus plantarum 423 isolated from sorghum beer. Biotechnol J 1:405-409.

Todorov SD (2008) Bacteriocin production by Lactobacillus plantarum AMA-K isolated from Amasi, a Zimbabwean fermented milk product and study of adsorption of bacteriocin AMA-K to Listeria spp. Braz J Microbiol $38: 178-187$.

Todorov SD (2009) Bacteriocins from Lactobacillus plantarum production, genetic organization and mode of action. A review. Braz J Microbiol 40:209-221.

Todorov SD, Botes M, Danova ST, Dicks LMT (2007) Probiotic properties of Lactococcus lactis subsp. lactis HV219, isolated from human vaginal secretions. J Appl Microbiol 103:629-639.

Todorov SD, Danova ST, Van Reenen CA, Meincken M, Dinkova G, Ivanova IV, Dicks LMT (2006) Characterization of bacteriocin HV219, produced by Lactococcus lactis subsp. lactis HV219 isolated from human vaginal secretions. J Basic Microbiol 46:226-238.

Todorov SD, Wachsman M, Tomé E, Dousset X, Destro MT, Dicks LMT, Franco BDGM, Vaz-Velho M, Drider D (2010) Characterisation of an antiviral pediocin-like bacteriocin produced by Enterococcus faecium. Food Microbiol 27:869-879.

Todorov SD (2010) Diversity of bacteriocinogenic lactic acid bacteria isolated from boza, a cereal-based fermented beverage from Bulgaria. Food Control 21:1011-1021.

Verellen TLJ, Bruggeman G, Van Reenen CA, Dicks LMT, Vandamme EJ (1998) Fermentation optimisation of plantaricin 423 , a bacteriocin produced by Lactobacillus plantarum 423. J Ferment Bioengin 86:174-179.

Vignolo GM, Dekairuz MN, Holgado AAPD, Oliver G (1995) Influence of growth conditions on the production of lactacin-705, a bacteriocin produced by Lactobacillus casei CRL-705. J Appl Bacteriol 78:5-10.

Yang R, Johnson M, Ray B (1992) Novel method to extract large amounts of bacteriocins from lactic acid bacteria. Appl Environ Microbiol 58:3355-3359.

Yildirim Z, Avsar YK, Yildirim M (2002) Factors affecting the adsorption of buchnericin LB, a bacteriocin produced by Lactobacillus buchneri. Microbiol Res 157:103-107.

All the content of the journal, except where otherwise noted, is licensed under a Creative Commons License CC BY-NC. 